\title{
Teachers' Attrition at Pre-tertiary Level in Ghana: A Qualitative Investigation into its Causes and Suggestions
}

\author{
Samuel Stevens Boateng \\ Valley View University. Department of Business Education, Oyibi - Campus,Accra-Ghana.
}

\begin{abstract}
Education has become an important social service, and its benefits are better reaped through quality of teachers who could improve performance of learners. However, in Ghana, before teachers gain experience they quit their profession, a behavior popularly known as attrition, now a global challenge. Attrition in Ghana dates back to President Nkrumah's era in the 60s, when His fee-free education attracted more children and consequently more teachers. However, conditions of service were un attractive at that time, so many vacated their posts to neighboring countries, like Nigeria, Liberia, Cote d' Ivo ire, etc. Till date the attrition rate is In Ghana is high. The study thus seeks to identify the causes of, and solution to the attrition challenge in Ghana. With a qualitative hermeneutic phenomenology methodology sampling approach, the researcher sampled for the study five teachers who had resigned their posts, and five who were in the Ghana Education Service. A qualitative study analysis software (NVivo), was used to generate four themes as follows: Poor conditions of service and salary; poor image of the profession; and a disunited front of the different groups of teachers-UTAG, POTAG, NAGRAT, and GNAT. The reviewed literature supported the first three themes, but the last one- the disunited front of teachers-- was significantly unique, and not found in previous studies. Recommendations to raise the image of the teaching profession through school curriculum review; better conditions of service for GES; and a united front for all teachers in Ghana have been suggested.
\end{abstract}

Key words: Attrition, greener pastures, qualitative genre, hermeneutic phenomenology

DOI: $10.7176 / \mathrm{JEP} / 10-14-18$

Publication date:May $31^{\text {st }} 2019$

\section{Introduction}

Formal education plays an enormous role in our present world of socio-economic development because it brings about knowledge and technology, which have become key tools in leveraging competitive advantage (Oduro, 2000). Baah, Otoo, and Osei-Boateng (2009) found that the quality of a country's stock of human capital directly influences the extent to which knowledge and technology can enhance productivity and improve the well-being of citizens. Salahu and Aminu's (2010) study concluded that education has become the most important social service in the world today, and without it, no nation can develop.

Calxton (2008) posits that internationally, without exception to Ghana, research studies have proven that lack of quality teachers inhibit good performance. Therefore, nations that ranked high on global assessment have established good policies to ensure that they deploy and retain qualified teachers. In Ghana, however, the situation is different. Wonyor (2006) found that the challenge of teachers' attrition in Ghana's pre-tertiary education system grew from worse to worst when Dr. Nkrumah extended the fee-free compulsory education to all parts of the country in 1961. This decision called for the extension of free compulsory education, which resulted in many children enrolling in schools, and thus increasing the need for more teachers. To increase teacher supply, government recruited untrained teachers to fill the gap, leading to too many children supposedly educated, but in reality, these children lacked quality education. Besides, the more government recruited more teachers, Wonyor claimed, the more the experienced ones left the profession.

\section{Problem Statement}

A study by Baah (et al., 2009) discovered that about $2 / 3$ of teachers in all sectors of education in Ghana were dissatisfied and often abandoned their posts, because Government was insensitive to their demands. This led to industrial action in all public schools (Adanusa, \& Demanya, 2014). In addition, there has been no legitimate policy to curb teacher attrition in Ghana (Baah, et al., 2009). The study of Ingersoll (2003) reported that annually, $15.7 \%$ of teachers stop teaching to join other professions, while government sponsored $40 \%$ of them to study further but do not return anymore to their profession (Wushishi, et al., 2014). Baah (et al., 2009) again found that 
there is a continued decline in the status of teachers and same has assumed a perceptive dimension, and has become the crucial part of the fight to retain teachers in the classroom. These findings reveal that, there is no comprehensive study about the perceptive underpinnings of the teacher attrition challenge in the Ghana Education Service (GES). Therefore, this study, investigates attrition among teachers in the GES, to fill the gap (perceptive underpinnings), and adds knowledge to the body of literature.

\section{Purpose of the Study}

The purpose of this study was to explore the possible reason(s) and solution to Ghana's pre-tertiary attrition challenge, which is now a worldwide problem (Appiah-Agyekum, Suapim \& Peprah, 2013). The study again, sought to determine whether there are, personal characteristics (demographics) associated with the attrition of teachers, and to determine the extent to which teaching and living conditions have become factors motivating teachers to quit or remain

\section{Objectives of the study are to:}

$>$ Find out why teachers quit their profession in pre-tertiary schools in Ghana.

$>$ Determine the strategies educational administrators should use to increase retention rates among teachers in Ghana.

\section{Research Questions}

$>$ Why do teachers quit their profession in Ghana's pre-tertiary education system?

$>$ What strategies can educational administrators use to increase retention rates among pre-tertiary teachers in Ghana?

\section{Significance of the study}

The study examined the hidden causes of attrition among teachers in Ghana Education Service (GES). When implemented, the findings of the study could help policy makers to develop policies that could reverse the downward trend of teacher morale and status, so they can remain in the service. The results of the current study should unravel not only causes of teacher attrition, the perceptive underpinnings of the teacher attrition challenge, and seek solution to it.

\section{Literature review}

\section{Causes of teachers quitting educational sector}

In Ghana the study of Sam, Effah and Osei-Owusu (2014) enumerated some factors that compelled teachers to quit teaching as low salaries, poor conditions of service, low status (prestige) for the teaching profession, and the lack of incentives associated with the job. Cobbold (2015) posits that teachers in Ghanaian public schools quit their post because they are not satisfied with their salaries. Van den Berg (2002) established that overemphasis on standards, a lack of participation in decision-making, failure to provide instructional resources, lack of support from administration, and lack of trust in the expertise of teachers increase job dissatisfaction and lack of retention of teachers. A similar study by Leimann, Murdock and Waller (2008) reported low salary of teachers as the key cause of attrition. In the view of Manna and Tesfay (2000) teachers quit their profession due to low recognition they receive from the general public, a perception that forces them to quit for a better job.

Researchers have identified other multiple reasons for attrition: Smithers and Robinson (2001) argued that teachers in the United Kingdom (UK) are quitting from the teaching profession because of workload. The World Bank Report (2007) hinted that teachers who consider themselves qualified are always unwilling to stay in the remote areas. The study of Akyeampong \& Lewin (2002) supported the study of World Bank Report (2007) that in Ghana, over 80 percent of teachers preferred to teach in urban schools. The study of Hanushek, Kain and Rivkin (2002) reiterated that poor professional working conditions play a substantial role in decisions to leave teaching in a particular school or district. Chediel (2010) hinted that teachers abandon the teaching profession to 
pursue further courses at the postgraduate level such as law, administration and information technology, which they consider to be lucrative than the teaching profession.

\section{Strategies to increase teacher retention}

Billingsley (2004) outlined some factors that influence teachers to remain in the profession as; good working conditions provided by school administrators; provision of conducive environment; decent relations among school directors/managers and teachers; reduction of workload and unnecessary stress. . Other researchers confirmed retention of teachers through mentoring and induction, financial incentives, and attractive salary as well as equal chance for teacher leadership (Lasagna, 2009; McInerney, Ganotice, King, Marsh and Morin 2015).

McCreight (2000) conducted a study at Texas A \& M University on teacher attrition, and noted that, national average for teacher salaries began at $\$ 26,000$, making it one of the lowest paid occupations for a college graduate. Lawyers and doctors earn 50\% to 75\% more than teachers. According to Falch (2010, 2011), Norwegian teachers were paid a wage of $10 \%$ as premium for teachers who teach in the less endowed schools with staffing challenges. Ghosh, Satyawadi, Joshi and Shadman (2013) suggested proper provision of opportunities for staff development, allowing staff to put up their best and express their views, to curb the attrition challenge.

Mkonongo's (2004) study encouraged retention through good economic, political and social conditions. Njunwa (2010) suggested provision of accommodation for teachers as part of the solution to the attrition challenge. HakiElimu (2010) believed that retention of teachers depend upon incentives for teachers posted to remote schools; upgrade of licensed teachers, and ensuring opportunities for professional growth through inservice training. Tawia-Armah (2010) outlined some condition that will attract teachers to stay in the profession as reduction of class sizes, accommodation for teachers, and teacher's involvement in decision-making.

\section{Methodology \\ Research Design}

A research design is a plan to achieve research objectives or answer research questions. It situates the structure or framework that will be used to solve the main research problem. While Sun (2009) identified five popular qualitative studies, Saldana (2011) listed 11 including that of Sun. Therefore, we examine the only five mentioned by these two popular scholars and assign reasons for adopting one for this study.

Qualitative Case studies deal with issues relating some weird happenstances such as a prodigy, or something that appears supernatural. Qualitative ethnography involves investigation into cultural experiences of specific groups of people. Grounded theory, as the name suggests, seeks to develop a theory where there is none to address a problem. Narrative Inquiry, deals with issues relating experiences in a chronological order, such as the biography of a particular person, out of which knowledge can be constructed. Phenomenology, on the other hand, is an investigation into lived experiences of participants for better understanding. This study therefore adopts hermeneutic phenomenology approach, where the researcher interprets lived experiences of the subjects of study, instead of describing them (Saldana, 2011; Sun, 2009; Park, 2006).

\section{Population and Sampling Technique}

The researcher selected five seasoned education officers and administrators; and five teachers who vacated their posts and were working in other fields where they felt more comfortable. These 10 participants informed the study. Creswell (2006) contended that a sample of 10 participants is a viable sample to receive reliable results since the researcher cannot generalize phenomenological research results.

Table 1 depicts the demographic data of the respondents. From that table, $60 \%$ of the participants are males, while $40 \%$ are females. Of the four females, however, only one was an education officer; the other three had vacated their posts. The males (six of them) were officers, and three had vacated their posts. This means $50 \%$ of the respondents had vacated their posts making data gathered, relevant and balanced. 


\section{Table1. Gender Distribution of Respondents}

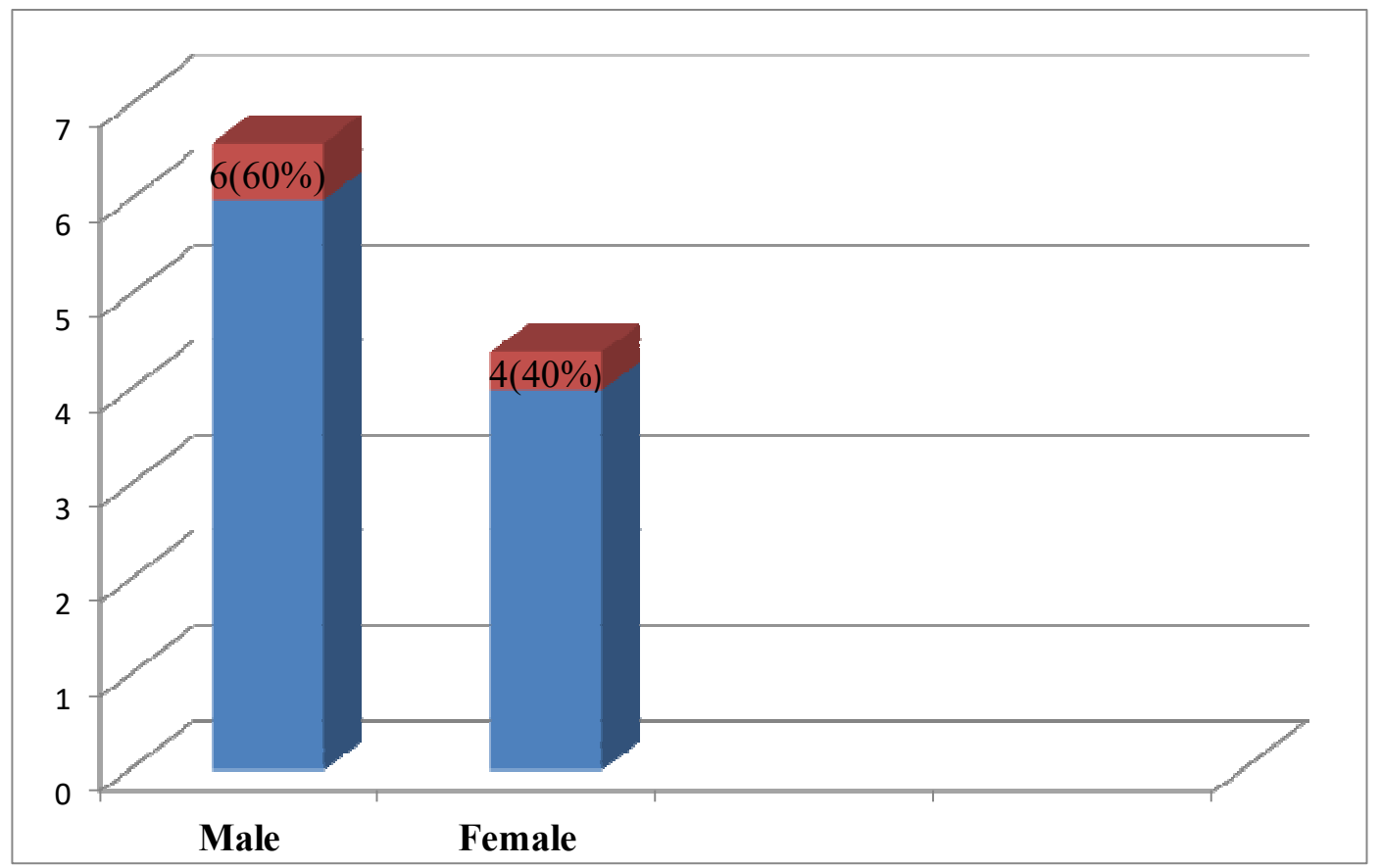

Source: Fieldwork, 2018.

Table 2 has details of the statistical data of participants. The oldest participant was 58years, and the youngest, 36. Three of them have M.Phil. The rest have degrees. Incidentally, the years of service of those who had resigned or vacated their posts paint an interesting picture: All but one of those who had resigned did not gain enough experience. Participants 2, 3, 4, and 10 served for 10, 5, and 6 years respectively in pre-tertiary schools. Participant 7 (53 years old) however served for 22 years and still decided to quit. All the participants at post served between 20 and 30 years. Therefore, those who vacated posts and those who resigned informed the study equally well.

Table 2: Statistics of respondents who had resigned and those at post

\begin{tabular}{|cccclc|} 
No & Age of Respondent & Qualification & Rank in GES & Status & Service years \\
\hline $\mathbf{1}$ & 50 & BA & AD & At post & 21 \\
\hline $\mathbf{3}$ & 39 & MA & Prin. Supt & Resigned & 10 \\
\hline $\mathbf{4}$ & 41 & MBA & Teacher & Resigned & 5 \\
\hline $\mathbf{5}$ & 39 & BA & Teacher & Resigned & 6 \\
\hline $\mathbf{6}$ & 43 & M.Phil & Prin. Supt & At post & 20 \\
\hline $\mathbf{7}$ & 36 & M.Ed & Director II & At post & 21 \\
\hline $\mathbf{8}$ & 53 & M. Phil. & Prin. Supt. & Resigned & 22 \\
\hline $\mathbf{9}$ & 43 & M.Phil. & Prin. Supt & At Post & 20 \\
\hline $\mathbf{1 0}$ & 58 & BA & Director II & At Post & 20 \\
\hline
\end{tabular}

Note. $\mathrm{RSP}=$ Respondent; $\mathrm{AD}=$ Assistant Director; Prin. $\mathrm{Supt}=$ Principal Superintendent Source: Fieldwork, 2018 . 


\section{Purposeful Sampling}

The researcher adopted purposeful sampling technique. Frankel and Devers (2000) posit that purposive sampling could help achieve the goals and logic of qualitative research. In this study, the researcher purposefully selected 5 teachers who had resigned and were ready to provide information about the causes of teachers' attrition in Ghana, and 5 who were at post to also share their views.

\section{Instrumentation}

Fraenkel and Wallen (2008) again posit that instrumentation is the entire method of data gathering and encompasses choice or design of the instrument, and the condition under which to administer it. Interview was the only instrument used to collect data. The researcher captured information from three participants via electronic format to obtain their transcribed feelings and ideas concerning behavior of teachers (Simon, 2005). However, 7 participants were interviewed through an audio tape recorder.

\section{Data Analyses and Results}

Simon (2005) found that analysis of results in any academic study is an important component of scholarly research. To Simon, analysis of the data requires creativity because the researcher takes raw data and organizes it into meaningful categories, while clearly explaining the interpretations of the information. In this study data were loaded unto an NVivo qualitative analysis software for themes that depicted the causes and remedy for attrition. Poor conditions of service and salary; poor image of the profession; and a disunited front of the different groups of teachers-UTAG, POTAG, NAGRAT, and GNAT. Recommendations to raise the image of the teaching profession through school curriculum review; better conditions of service for GES; and a united front for all teachers in Ghana have been suggested.

\section{Findings}

\section{Objective One}

Objective one of this study considered reasons why teachers quit pre-tertiary schools in Ghana. Two themes emerged as follows: poor conditions of service; poor salary; and poor image of the profession. Almost all the 10 respondents spoke about these themes in one way or the other.

\section{Poor conditions of service:}

The first respondent (RSP1), said, the main reason I quit GES is lack of job satisfaction. The second (RSP2) shared that most teachers leave the service because of the poor conditions of the service. Therefore, once they upgrade their educational status, they begin to find interest in more lucrative jobs.

The third respondent added that teachers live with other professionals within the same communities and are witnesses to the benefits, and how society regards them.

The fourth (RSP4) exclaimed ah! Thank you. I think that greener pastures, it means where they are, are not green, so obviously they want something that is green. The conditions of service in education in Ghana in particular is very bad: Classroom, poor infrastructure... remuneration in terms of how much the person takes home.... It was in the news that some have taught for 3 years in the Eastern Region, no salary.

The sixth (RSP6) revealed that some of them (teachers) teach for two years without salary... so they begin... to nose around and hear where salaries and conditions of service are better than... and then they quit!

(RSP8) It is true most teachers leave their professions; and, one; is because when you are working you need to get job satisfaction...in the environment. You know when they compare themselves with other colleagues elsewhere; and they see the bullying, their job, the environment, they think that look, where they are, they have to go ahead to somewhere else. So most of the time, the idea is to move from where they are to other places.

The tenth (RSP10) posed three powerful arguments: One, when a teacher is even sick, and then, you want to present your medical report; the hustle you go through before you even take your money is a big challenge...and the amount of money that they will give you, would not take you anywhere. Number two, is the environment, where we work..., and you even want a place of convenience, you would not get on your compound, which is number one thing that put me off. Then another thing too, the most painful one is, I got opportunity to do my 
Masters' degree in Adult Education and when I finished, I presented my certificate to the Regional Office through the headquarters. I was finally told that the course I did is not relevant to GES.

\section{Poor Image of the profession}

The fifth respondent (RSP5) dwelt on 'rewards;' when you teach you are given the least reward in society. Moreover, today, if you want to mention people who are working, and are poor in society they easily cite teachers. Watch the TV and they are telling you that even if you are a teacher you can buy this item. What is the implication? They are placing the teacher below, of course which is true.

The seventh (RSP7) respondent stressed on the image of the teacher and frowned on the perception that people have concerning teachers, that they are poor.

Respondent Nine (RSP9) recalled, When I finished the University in the early 1990s, and I needed to come back to the Ghana education service. I travelled from district to district; and I met the deputy director and I was so frustrated, you know... and I had waited for him; they told me he was out and just as I was coming down somebody pointed at him; "oh this is the district director." I attempted to greet and talk to him, but he shouted at me; and that was very demoralizing!

\section{Strategies to Increase Teachers' Retention}

Objective two of the study sought the views of respondents on the strategies to increase teacher retention. Below are the responses and suggestions from all the 10 respondents.

\section{Better Salaries Preferred}

(RSP1): Our conditions of service should be improved. Teaching and learning materials should be provided and salaries should be made better. (RSP2): added that professions such as the health and banking sectors are well paid. They have very good conditions of service.

(RSP3) believed in the following retention strategies:

1. Good interpersonal relations from Directors, Circuit Supervisors, Headmaster/Mistresses.

2. Prompt promotions and upgrades of teachers after further studies.

3. Benefits-in-kinds

4. Commensurable salaries, allowances and other encumbrance.

(RSP4) said frankly: The salary is not enough; ... I mean how can a Minister of state take GHc10, 000; GHc7, 000 etc., a month. Then a teacher will go and take Ghc500 a month, no allowance. I mean, it is a misplaced priority. The government should reduce these salaries and bring it to the teachers.

(RSP5) argued that to retain teachers, there are other benefits; motivation is got not to do with salaries. When a doctor sends his child to the hospital, he is just treated for no payment. He even receives courtesy in the treatment. A teacher sends his child to school and you pay every dime, to the last pesewa, and you do not have any preference. When a police officer's son gets a problem; he is taken to the law all right, but there are certain curtsies and limitations...there are no allowances, there is nothing. So even if you increase salaries, and I still have a lot of things to use that increased salary to take care of, in the next results it will be low.

(RSP6) reported that the low salary structure, needed to be increased; he argued that other factors lowered the teacher's status. You know in the olden days in spite of the low remuneration in service people respected teachers. However, these days it is not only the conditions of service that bring the status of the teacher low...

This response is in consonance with that of the seventh respondents (RSP7): Many people think that teachers are poor, so majority of the respondents don't want their wards to join the profession, though it is noble profession... those who are not born into the job, always search for the salaries and then move for the better.

(RSP8) mused: I think basically, when you talk regarding teachers, it is the salary; is the salary; although the environment counts, it is the salary, because they always say teachers' salaries are low.

(RSP9) believed that, there are some improvements in the remuneration package of teachers but it was not attractive enough compared with other packages of the same qualification in other organizations. According to the respondent, there is some improvements... But, the terms are not so much attractive as compared to.... So it 
makes some of the teachers' still want avenues, to leave to have some accommodation.

On the contrary, while the ninth respondent indicated salary improvement, the tenth respondent (RSP10) said ...the salary was not something to take home. At least salaries; something must be done about the salaries. I think salaries for teachers should, be seriously looked at. Then, apart from the salaries as I think and always said conditions of service, must be improved, must be improved!.

\section{A United Front}

(RSP1) believed that teachers must be united to be able to gain what can make them stay in the service. This is what he shared:

If they (teachers in Ghana) have a common front, a single mouthpiece and that makes them strong and united. In Ghana, we have Ghana National Association of Teachers (GNAT); National Association of Graduate Teachers (NAGRAT); Polytechnic Teachers' Association of Ghana (POTAG); and University Teachers Association of Ghana (UTAG) etc. Professions with a common voice most often have their grievances addressed earlier by government and other stakeholders than those with divided fronts.

\section{Discussions}

\section{Objective One: Why Teachers of Quit Pre-tertiary Schools.}

\section{Poor conditions of the service}

The literature is replete with the effects of poor conditions of service in the pre-tertiary education system of Ghana. Seven of the respondents strongly believed that poor conditions of service is the main cause of pretertiary attrition. Respondents mentioned lack of job satisfaction, delay in payment of salaries, poor infrastructure, and medical attention policies, as factors that pushed out many teachers from the pre-tertiary level. Ghana News Agency as reported by Ababu (2018) had revealed the shocking news that about 7000 teachers quit the pre-tertiary level annually. Mfaume (2012, p 64) confirmed a respondent saying that "he has nothing to lose" and that if he was terminated he would "quit quickly."

Van den Berg (2002) established that overemphasis on standards, a lack of participation in decision-making, failure to provide instructional resources, lack of support from administration, and lack of trust in the expertise of teachers increase job dissatisfaction and lack of retention of teachers. The study of Hanushek, Kain and Rivkin (2002) reiterated that poor professional working conditions play a substantial role in decisions to leave teaching in a particular school or district.

RSP 9 has shared the frustration he experienced while he was looking for a station after his training and how a big officer in the service denigrated him. His finding is consistent with the experience of Smithers and Robinson (2001), "teachers in the United Kingdom (UK) are quitting the teaching profession because of workload." However, the heavy workload brings about frustration, but the frustration of this officer (RSP9) was unique; in fact psychological. While the officer did not quit because of his experience, however, some do, and that is not good for the profession.

What RSP10 shared corroborates the finding of Adoniou (2013) that teacher attrition in Australia is not only money that forces teaching professionals to quit since higher pay did not help to improve teacher retention. According to the study, in spite of all the increment in teachers' salaries, they still quit the profession due to poor working environment and conditions.

\section{Poor Image of the Profession}

The fifth respondent had shared that some societies in Ghana look down upon teachers; he stated: Watch the $T V$ and they are telling you that even if you are a teacher you can buy this item. What is the implication? They are placing the teacher below, of course which is true. The study of Ingersoll (2001) reported that teachers leave because of poor self-image due to poor working conditions than salary as perceived by the public.

\section{Objective Two}

\section{Strategies to Increase Teacher Retention \\ Better Salaries}

Respondents cried for better salaries as a way of retaining teachers-RSP 8 \& 9. Better salaries denote 
incentives for teachers. Cobbold (2015) posits that teachers in Ghanaian public schools quit their post because they are not satisfied with their salaries. McCreight (2000), however, believes that offering loan forgiveness programs, raising public awareness, training paraprofessionals; and awarding conditional loans, could be achieved if Ghanaian teachers had a united front as we have in other professional fields.

\section{United Front}

The first respondent's message about a united front also echoes the finding of McCreight (2000).

According to RSP1 if all teachers' association in Ghana (GNAT, NAGRAT, POTAG, and UTAG) unite they could find solution to the challenge of attrition which is due to poor working conditions and salaries.

McCreight (2000) believes that what teachers need to remain in the profession is simply; good conditions of service. RSP1 had noted that with a united front they could achieve their needs, because Governments and organization are forced to meet the needs of workers when they unite. Ghana Education Service (GES, 2002) provided incentives like motor bikes and other incentives to bait teachers to rural schools but it did work. Billingsley (2004) and Michaelowa (2002) are of the opinion that improved salaries alone is not the solution to teacher retention. Therefore, a United Front to fight for the much-needed condition of service would be a panacea to Ghana's pre-tertiary attrition challenge largely.

Tawia-Armah (2010) and Njunwa (2010) found that communities in Districts could be involved in creating good environment for teachers in schools through building houses for them - a retention strategy-but this venture cannot be achieved if teachers continue to be in scattered groups as shared by RSP1.

\section{Conclusions and Practical Recommendations}

\section{Conclusions}

Findings of the research questions were interrelated and one could easily see a simple thread - Poor conditions of Service; poor salary structure; poor image of the Profession; and a disunited front of teachers. Why teachers quit their profession is not only a problem in Ghana, but also a worldwide phenomenon. The first and most important finding is poor conditions of service. Almost all ten respondents were not happy about the poor conditions of service: poor infrastructure, lack of washroom facilities in some schools; lack of teaching and learning materials; undefined promotion systems; delay in the payment of teachers' salaries; low salary structure, no allowances and incentives in the profession, etc.

Another theme is poor image of the profession: The study revealed some Ghanaian societies look down on the profession as a poor one, while some officers bully and look down on teachers they serve. Finally, the study revealed that teachers have disunited fronts with four Union groups: GNAT, NAGRAT, POTAG, and UTAG. With a united front, teachers could fight for their rights, and think as a unified body to raise the image of the profession, and gain their needs. The listed anti-teacher retention factors could be easily resolved if Ghanaian pre-tertiary teachers were united. In unity, teachers could fight for their common needs and rights.

\section{Recommendations}

Based on the findings of the study, the following recommendations could reduce the attrition challenge in Ghana. First, conditions of service in the GES have been unacceptable. A teachers' fund is recommended to improve the situation. Whoever can read and write and is working must be taxed a small sum of money monthly towards the fund that could raise the image of the profession. Donors could show their concern for the profession that made them what they are by patronizing that fund.

Secondly, a united front is recommended as a way of maintaining and retaining teachers. Should all teachers come together as one body to form one association; first, their dues could be channeled through investments, and used as welfare schemes. When these associations unite, attendance of conferences exchange and sharing of ideas, etc., could make them an invincible force to fight for their rights, and thus assist national development in a positive dimension.

Apart from that, there should be a nationwide education on the value of education, and the need to respect the teacher and the teaching profession in general. In view of this, the development of a curriculum that will begin to educate learners' right from infancy to University to redeem the image of the teaching profession will be in order. 


\section{Recommendations for further research}

Quantitative researchers could investigate and confirm the authenticity of this study, since we cannot generalize the results of a qualitative research (Creswell, 2005; Saldana, 2011).

\section{References}

Ababu, A. (August 24, 2018). 7000 Teachers quit annually-GNAT. Ghanaian Times \# 18,392, p. 13.

Adanusa, I. D. (2014, May 22). Press statement on unresolved grievances of teaching employees GNAT News. Retrieved from http://www.openequalfree.org/ed-news/crisis-of- teacher -attrition-in-Ghana.

Adoniou, M. (2013). Why good teachers leave teaching. http://theconve rsation.com/ why-good-teacher s-leaveteaching-21339.

Akalewold, B. (2004). Participation and educational change: Implications for educational reform in Papua New Guinea. Papua: University of Papua New Guinea Press.

Akyeampong, K., \& Lewin, K. (2002). From student teachers to newly qualified teachers in Ghana: Insights into becoming a teacher. International Journal of Educational Development, 22, 339-352.

Alan, P., \& Pamela, R. (2003). Factors affecting teachers'decision to leave teaching profession. Retrieved from https://www.researchgate.net/ publication/266473184__ factors_ Affecting_ Teachers '_Decisions_to_Leave_the_Profession.

Appiah-Agyekum, N. N., Suapim, R. H., \& Peprah, S. O. (2013). Determinants of job satisfaction among Ghanaian teachers. Journal of education and practice, 4(3), 43-50.

Baah, Y., Otoo, K. N., \& Osei-Boateng, C. (2009). Teacher attrition in Ghana: Results of a questionnaire survey. Ghana National Association of Teachers (GNAT) \& Teachers and Educational Workers Union (TEWU), 142 .

Billingsley, B. S. (2004). Special education teacher retention and attrition, a critical analysis of the research literature. The Journal of Special Education, 38(1). 39-55.

Boyd, M. T., Lankford, E., Loeb, M. S., \& Wyckoff, T. (2007). What teacher educators and researchers should know. Teacher Education and Special Education, 20(4), 349-359.

Boyd, D., Goldhaber, D., Lankford, H., \& Wyckoff, J. (2007). The Effect of Certification and Preparation on Teacher Quality, The Future of Children, 17, 1, 45-68

Calxton, J. E. (2008). Retaining quality teachers. High School Journal, 86(1), 57-75.

Chapman, D. W., \& Hutcheson, S. M. (1982). Attrition from teaching careers; A Charter, M. A. (1970). Teachers' satisfaction with teaching. The Journal of Educational Research, 75(4), 241-247.

Cobbold, $C$. (2015).Solving the teacher shortage problem in Ghana: Critical perspectives for understanding the issues. Journal of Education and Practice, 6(9), 71-79.

Creswell, J. W. (2005). Educational research: Planning, conducting, and evaluating quantitative and qualitative research. Upper Saddle River, NJ: Pearson Education.

Creswell, J. (2006). Qualitative inquiry and research design: Choosing among five traditions (2 ${ }^{\text {nd }}$ Ed.). Newbury Park, CA: Sage.

Demanya, M. V. V. K. (2014). Press release Christmas and New year. GNAT News (December 24).

Ekundayo, H. T . (2010). Administering secondary schools in Nigeria for quality output in the 21st Century: The principals' challenge. European Journal of Educational Studies , 2(3).

Falch, T. (2011). Teacher mobility responses to wage changes: Evidence from a quasi-natural experiment. American Economic Review: Papers and Proceedings, 101, 460-465.

Falch, T. (2010). The elasticity of labor supply at the establishment level. Journal of LaborEconomics, 28, 237266.

Frankel, R. M. \& Devers, K. J. (2000). Study design in qualitative research-2, Sampling and data collection strategies. Education for health. 13(2), 263-271.

Gratton, L. (2007). Hot Spots: Why some teams, work places, and organizations buzz with energy and others don't. San Francisco, CA: Berrett Koehler Publishers, Inc. 
Ghosh, P., Satyawadi, R., Prasad-Joshi, J., \& Shadman, M. (2013). Who stays with you? Factors predicting employees' intention to stay. International Journal of Organizational Analysis, 21(3), 288-312.

Guarino, D., Santibanez, H., Daley, R., \& Brewer, A. (2004). Teachers' and researchers' collaboration in analyzing mathematics teaching: A context for professional reflection and development. Journal of Mathematics Teacher Education, 6, 473-485

Haki--Elimu, (2004). Hali ya Kazi na Maisha ya Walimu Tanzania. Matokeo ya ripoti ya utafiti. HakiElimu Brief Na. 06. 3K.

Hanushek, E. A., Kain, J. F., \& Rivkin S. G. (2002). Inferring program effects for specialized populations: Does special education raise achievement for students with disabilities? Review of Economics and Statistics, 8(4), 584-599.

Ingersoll, R. (2001). Teacher turnover and teacher shortages: an organizational analysis. American Educational Research Journal, 38(3), 499-534.

Ingersoll, R. (2013, October) Why Do Teachers Quit? The Atlantic Magazine. Retrieved from www.theatlantic.com/education/archive.

Lasagna, M. (2009). Increasing Teacher Retention to Facilitate the Equitable Distribution of Effective Teachers. Washington, DC: Learning Point Associates.

Leimann, K., Murdock, G., \& Waller, W. (2008). The staying power of mentoring. Delta Kappa Gamma Bulletin, 74(3), 28-31.

Mampane, P. M. (2012). The Teacher Turnover Crisis: Evidence from South Africa. Business Education \& Accreditation, 4(2), 73-83.

Manna, O., \& Tesfay, S. (2000). Determinants of teachers' decision to leave or stay in the teaching profession. The Ethiopian Journal of Education, 20, 1-24.

McInerney, D. M., Ganotice, F. A., King, R. B., Marsh, H. W., \& Morin, A. J. (2015). Exploring commitment and turnover intentions among teachers: What we can learn from Hong Kong teachers. Teaching and Teacher Education, 52, 11-23.

McCreight, C. (2000). Teacher attrition, shortage, and strategies for teacher retention (ERIC Document No. ED444986). Retrieved from www.eric.ed.gov

McWilliams, H. O. A., \& Kwamena-Poh, M. A. (1975). The development of education in Ghana. London: Longman Group Ltd.

Mfaume, H. (2012). The Role and Contribution of the Teacher Service Department in the Promotion of Teacher Ethics in Tanzanian Secondary Schools. A Case of Mbeya Municipality and Mbeya Rural District. (Unpublished Master's Dissertation).University of Dar es salaam. Dares salaam.

Michaelowa, K. (2002). Teacher job satisfaction, student achievement and the cost of primary education in Francophone Sub-Saharan Africa. Paper presented at the Hamburgischer Welt-Wirtschafts Archiv(HWWA) discussion paper 188, Hamburge Institute of International Economics.

Mkonongo, P. K. (2004). Retention of Graduate Teachers in Secondary Schools in Tanzania. M.A (Education) Dissertation, University of Dar es Salaam.

Monney, K. A. \& Anthony - Krueger, C (2009). Perceptions of Science Teachers about factors affecting their Retention in Senior Secondary Schools in Ghana: Ghana Journal of Education: Issues and Practice. Vol. 1(1) April 2009.22-28. University of Cape Coast. Ghana.

Motuma H (2006). A study of teacher's turnover in Oromia Regional state of selected zones. Unpublished master's thesis, Addis Ababa University, Ethiopia.

Njunwa, K. M. (2010). Community Participation As A Tool For Development: Local Community's Participation in Primary Education Development in Morogoro, Tanzania. A case of Kilakala and Mindu Primary Schools. Master Thesis in Development Management, University of Agder. Centre for Development Studies.

Oduro, A. D. (2000). Basic education in Ghana in the post-reform period. Accra: Centre for Policy Analysis.

Salahu, M. L., \& Aminu, A.W. (2010). History education for national development. Journal of Educational Studies, 2(3), 223-232

Saldaña, J. (2011). Fundamentals of qualitative research. 12, 139-158. New York, NY: Oxford University Press. 
Sam, F. K., Effah, B., \& Osei-Owusu, B. (2014). Exploring issues of teacher retention and attrition in Ghana: a case study of public senior high schools in Kwabre East District of Ashanti Region-Ghana. Journal of Education and Practice, 5(1), 83-89.

Simon, M. (2006). Recipes for success: Dissertation \& scholarly research. Dubuque, IA:Kendall/Hunt.

Smithers, A., \& Robinson, P. (2001). Teachers leaving: A report for the National Union of Teachers. Liverpool: CEER.

Sun, T. Q. (2009, January 31). Mixed method research: Strengths of two methods. Internal document, Swiss Management Center University. Switzerland.

Tawia-Armah, G. (2010). Teacher motivation in selected senior high schools in the Kwabre District of the Ashanti Region. (Master of Arts Degree in Human Resource Management), University of Cape Coast, Cape Coast, Ghana.

Van den Berg, R. (2002), “Teachers"e meanings regarding educational practice”, Review of Educational Research, $72,577-625$.

Wonyor, Z. A. (2006). Factors affecting recruitment and retention of basic schoolteachers in Akatsi District of Ghana. Cape Coast: Published dissertation, downloaded 23 ${ }^{\text {rd }}$ Oct. 2018

World Bank Report. (2007). Education for All: Meeting our collective commitments. The Dakar Framework for Action. Retrieved from www.unes doc.unesco .org/images/00 12/001211/ 12114 7e.pdf

Wushishi, A. A., Fooi, F. S., Basri, R., \& Baki, R. (2014). A qualitative study on the effects of teacher attrition. International Journal of Education and Literacy Studies. 2(1), 12-16 